\title{
Ukrajinský fenomén v próze
}

\section{Viera Žemberová}

\begin{abstract}
Abstrakt
Ukrajinská literatúra žije prítomnostou a literárnou tvorbou autorov, ktorí posledné dve desatročia rázne vstupujú do toho, čím sa pod povrchom spoločenskej minulosti trápili ich rodiny aj jednotlivci. Tematizuje traumy, ale aj hodnoty prírodného prostredia, z ktorého vyšli a vzpierajú sa svojou tvorbou svetu, v ktorom musia znova žit, a pritom to nie je to, čo si želajú a nie vždy s tými, ku ktorým sa svojimi zámermi hlásia. Anticipačná sila umeleckého slova im dáva nateraz nádej, že zmena v mravoch a hodnotách ich súčasníkov predsa len prichádza a tomu procesu je potrebné pomáhat' jasnými postojmi k reáliám spoločenskej prítomnosti
\end{abstract}

\section{Klúčové slová}

ukrajinská moderná próza; čas; priestor; autenticita; tematizovanie spomienky

\section{Abstract \\ Ukrainian Phenomenon in Prose}

Ukrainian Literature lives the presence and literary works by the authors who in the period of the last two decades resolutely enter into what their families and individuals suffered below the surface of social history. It thematises trauma as well as the values of the natural environment from which the authors came out. Through the literary work, they defy to the world in which they have to live again, yet this is not what they desire and not always those who they tend to live with. Anticipatory power of artistic words gives them a hope for now that the change in morals and values of their contemporaries nonetheless comes and the process requires help through clear attitudes to the reality of the social presence.

\section{Key words}

Ukrainian modern prose; time; space; authenticity; thematicized memories 
Zakaždým potrebujem trochu času na to, aby som si pripomenul, ako teraz treba žit. ${ }^{1}$

Útrapy zo spoločenských rozpomienok a obnovovaná osobná nádej, i tak by bolo možné zovriet’ naračnú stratégiu Tarasa Prochasku. Prostredníctvom literárneho času, ktorý látkou a tematikou sa sústred’uje na literárnu skúsenost̉ a rozprávačskú zručnost̉ tvorcu, ten prostredníctvom epického príbehu domýšla reálie svojho i národného života, na podloží komorne pôsobiaceho subjektu postupne a nenáhlivo sa formuje prototyp vnímavého, vzdelaného ukrajinského literárneho človeka stredného veku v jeho jednotlivosti aj intímnosti, v jeho emotívnom aj bytostnom spojení s rodinou a krajom, v ktorom žije a prostredníctvom spomienok poznáva predovšetkým seba v čase a situácii, pretože ony rozhodujú o ňom ako o autentickom subjekte.

Taras Prochasko v role spisovatela a kultúrneho esejistu patrí medzi subtílnych zaznamenávatelov a zhodnocovatel'ov najskôr intímneho času subjektu obsiahnutého v pojme život a jeho prostredníctvom sa venuje závažným spoločenským kontextom dejinného univerza v premenách ukrajinskej spoločnosti raz v materializovanom priestore a inokedy v dramatických dejoch, aby svojho protagonistu vymedzoval ako nástroj aj obet udalostí utvárajúcich vel'ké dejiny či latentné dotykové miesta s prítomnostou tak svojou, ako aj svojho národa.

Prochaskov rozprávač zvýrazňuje všetko, čo súvisí s jeho etnicitou prostredníctvom národného ukrajinského jazyka a s objektívnou geografiou ${ }^{2}$, pritom predpokladá, že geopolitické reálie tematizovaných osobných a autobiografických príbehov a osudov nie je potrebné vysvetlovat', a to hned' z viacerých príčin. Podstatná príčina bude najskôr tá, že dejiny jeho krajiny a národa sú vo svojej vnútornej konštante minulého storočia známe, no premenlivá, žitá či tematizovaná prítomnost̉ vo svojej dynamike nemôže byt’ zhodnocovaná inak, teda len tak, že je zaznamenávaná subjektom a ilustrovaná na prežitom, čím sa zbližujú rozprávač a ním pripomínané geopolitické reálie (ZSSR, sovietsky spoločenský úzus, Brežnevove texty Malá zem, Obrodenie, Celina, Spomienky³), nadčasové kultúrne, autorské a poznávacie hodnotové iniciácie (Dejiny stredovekej pravoslávnej cirkvi, Balzac, Stefanyk, Čechovove denníky, Škl’arskij, Doktor Faust, ukrajinsko-nemecký slovník), obnažovanie subjektívnej etnickej identity (čeština - české rodinné korene) ${ }^{4}$, tragédie v pamäti ukrajinského národa aj v rozprávačovej rodine (dve európske vojnové katastro-

1 Taras Prochasko je vyštudovaný botanik, v ukrajinskej kultúre patrí do zoskupenia stanislavovský fenomén spolu s Jurijom Andruchovyčom. V češtine vyšla próza PROCHASKO, Taras: Jinaci. Praha: Pavel Mervart, 2013. V slovenčine vyšiel súbor dvoch próz PROCHASKO, Taras: $Z$ toho sa dá spravit’ niekol'ko poviedok. Bratislava: Brak, 2015.

2 Odkazujeme na názvy miest, pomenovania prírodných reálií v areáli, na emocionálnu hodnotu symbolu Karpaty, familiárne pomenovania členov rodiny, priezviská verifikovatel'ných neliterárnych postáv, s ktorými má rozprávač zámer v príbehu atd'.

3 PROCHASKO, Taras: Z toho sa dá spravit niekol'ko poviedok. Bratislava: Brak, 2015, s. 46.

4 PROCHASKO, Taras: Ako som prestal byt' spisovatel’om. Bratislava: Brak, 2015, s. 60: „Z jednej štvrtiny som predsa Čech. Ale ani sám neviem, prě̌o češtinu neovládam. Prečo som sa ju vôbec nepokúsil naučit. Neviem, či $v$ tomto zmysle nie je moja absolútna ukrajinskost' práve tou zatvrdelostou, ktorá ma na Ukrajincoch tak rozčul’uje. Nerozumiem, prě̌o som pred tým utekal ako diet’a a prečo stále utekám." 
fy, NKVD, Gmünde ${ }^{5}$, Varšavská zmluva) a napokon jemu citovými vztahmi a rešpektom i rolou v jeho osobnom príbehu nadovšetko blízke postavy (ujček Vlodko, lekárka babka Zoňa, český dedo, otec učitel', dvaja synovia) ${ }^{6}$.

Avšak nielen cyklické dejiny kultúry svedčia o tom, že po štýlovej čistote prichádza eklektizmus, po modernizme postmoderizmus, po renesancii manierizmus a po baroku rokoko?

Novinár a prozaik Taras Prochasko ${ }^{8}$ podl’a mapovania súčasnej ukrajinskej literatúry patrí do spoločenstva literátov, ktorí sa identifikujú väzbou na región a lokalitu ${ }^{10}$, teda medzi autorov prozaickej tvorby tzv. stanislavovského fenomému. S autormi stanislavovského fenoménu sa spája v modernej ukrajinskej literatúre proces „konstituováni postmoderniho diskurzu“11. Emancipácia ukrajinskej národnej literatúry v poslednom polstoročí predstavuje pre literárnu históriu členitú štruktúru rozličných požiadaviek, kritérií i spôsobov organizovania literárneho života ${ }^{12}$. Sprítomnenie postmoderny, s ktorou v literárnej estetike svojich textov pracujú autori stanislavovského fenoménu znamená i to, že „Postmodernizmus aktivizoval smíchovou, karnevalovou kultúru ${ }^{13}$, tzn. grotesku, ironii, parodii, absurdni prvky, kombinoval (či př́mo „prohazoval), vysoké/nizké, komické/tragické apod., čimž začal intenzivně narušovat stabilni hodnotový systém, souvisejici s pojmy podstatnými pro pojetí národní literárni tradice a národni identity jako takové, což často způsobovalo skandálni (ne)přijeti děl některýh autorů. Hravá karnevalová postmoderni tvorba je nejuýrazněji reprezentována

5 Ibidem, s. 69: „Gmünde (podl'a Encyklopédie ukrajinistiky): mesto v dolnom Rakúsku, ležiace na hranici s Československom, štyritisic obyvatelov; v rokoch 1914-1918 tam bol zriadený tábor pre utečencov a vysídlencov z Haliče [...], v rokoch 1914-1918 v Gmünde zomrelo takmer štrnásṫtisíc Ukrajincov."

6 Ibidem, s. 58, 74 .

7 Ibidem, s. 61.

8 Wikipedia uvádza autorovo meno Taras Bogdanowicz Prochasko (16. 5. 1968).

9 CHLAŇOVÁ, Tereza a kolektiv: Putováni současnou ukrajinskou literární krajinou. Prozaická tvorba představitelů tzv. „stanislavského fenoménu“. Praha: Pavel Mervart, 2010.

10 Ivano-Frankivsk, pôvodné historické meno lokality je Stanislavov.

11 Pozri Alexej Sevruk, Tereza Chlaňová. In: CHLAŇOVÁ, Tereza a kolektiv: Putováni současnou ukrajinskou literární krajinou. Prozaická tvorba představiteli tzv. „stanislavského fenoménu“. Praha: Pavel Mervart, 2010, s. 59-80.

12 Patrik Orieško zhodnocuje situáciu v ukrajinskom literárnom živote ako extrovertnú, a to preto, lebo „Ukrajinská literárna veda a literárna kritika dost’ neštastne delí ukrajinskú literatúru na generácie [...] a zarad’uje do nich bez ohl’adu na akékol'vek poetologické súvislosti, prakticky všetkých autorov, ktori debutovali v tom ktorom desatroč “. Tento záver podporuje aj príspevok Alexeja Sevruka a Terezy Chlaňovej. Role autorů tzv. stanislavského fenoménu při konstituováni postmoderného diskurzu v ukrajinské literatuře. In: CHLAŇOVÁ, Tereza a kolektiv: Putováni současnou ukrajinskou literárni krajinou. Prozaická tvorba představitelů tzv. „stanislavského fenoménu“. Praha: Pavel Mervart, 2010, s. 59-80.

13 Azda má zmysel pripomenút v tejto súvislosti prirodzenú a ukazuje sa, že aj latentnú dispozíciu ukrajinskej literatúry, ktorou sa vyčleňovala napríklad z konceptu národných literárnych romantizmov východoeurópskeho kultúrneho priestoru v predminulom storočí. 
programově provokativním literárním uskupením Bu-ba-bu, vytvořeným Jurijem Andruchovyčem, Jurijem Neborakem a Oleksandrem Irvancem v roce 1985 ve Lvově ${ }^{\text {«14 }}$.

Prochasko si osvojil láskavú iróniu voči času i tematizovanému ja. Z komponentov literárnej estetiky prečnieva vizuálny a kolorovaný pohlad na prírodný priestor, emóciami sprevádza všetko, čo sa dotýka jeho širšej rodiny a detí. Kým vyšiel súbor dvoch próz so sugestívnymi názvami, najskôr s relativizovaným žánrovým rámcovaním $Z$ toho sa dá spravit’ niekol'ko poviedok a po nej tenzijne polarizovaná (ne)literárne komponovaná autorská podstata, Ako som prestal byt' spisovatel’om, vyšiel v češtine text Jinaci (2013).

Neliterárne reálie nedávnej ukrajinskej spoločnosti ${ }^{15}$ sa v literárnom výraze personalizujú, sformovali sa do (generačného, skupinového) látkového podložia a tematizovaného zdroja na zobrazenie rozčarovania aj odstupu od nových, neželaných spoločenských praktík. Azda výraznejšie prečnieva poznanie sklamania, rezignácie, tematizovanie smrti a smútku v próze v noetickej línii iniciované tým, že sa očakávané i prislúbené želanie zo slobody, spravodlivosti a hodnôt nestalo skutočnostou a krivdy spáchané na životoch ich rodičov a príbuzných nedokážu ich deti uskutočnit (Oksana Zabužko ${ }^{16}$, Jurij Andruchovyča, Dmytro Kešel', Taras Prochasko a d’alší1 ${ }^{17}$. Vratkosť času, tlak skúsenosti a intímna pamät rodu pomkýnajú moderných ukrajinských spisovatel’ov k výpovedi s atakom na obnažovanie obsahu dejín, na prítomnost', ktorá sa vymyká očakávaniam aj nádeji na spravodlivoste, rovnost', vol'nost' a tvorivost'. Próza týchto autorov sa odlišnou poetikou sústred'uje na subjekt v retazci rodu so želanou mravnou a hodnotovo vymedzenou povinnostou, byt jeho pokračovaním v čase, priestore, v udalostiach a v praktikách vztahu moci voči jednotlivcovi: „Dedka (Mychasa) využívali na súkromné práce najskôr jeremčivskí a potom aj nadvirňanski splnomocnenci. Nebolo na tom nič zuláštne. Na konci osemdesiatych rokov sme aj my vojaci sovietskej armády opravovali dôstojnicke byty. "18 Moc sa v prózach súčasných ukrajinských prozaikov tematizuje ako takmer nezvládnutel’ná prekážka z l’udského zla a neprávosti, z neodčinitel’nej, ale nikdy nie zabudnutej krivdy na skaličenom živote, slobode, profesii, na rodine, ktorú po sebe zanechala personalizovaná a ideológiou udržiavaná minulost'. Tá si však svoje účty aj po spoločenskej zmene vyberala nad’alej: „Skôr ako sa obesila, priniesla $k$ nám pani Iryna strieborný servis a poprosila nás, aby sme ho odovzdali

14 CHLAŇOVÁ, Tereza: Putováni ukrajinskou literárni krajinou posledního prilstoletí. In: CHLAŇOVÁ, Tereza a kolektiv: Putováni současnou ukrajinskou literárni krajinou. Prozaická tvorba představitelü tzv. „stanislavského fenoménu“. Praha: Pavel Mervart, 2010, s. 38-39.

15 Ukrajinskí autori súčasnosti sa spravidla pohybujú v dvoch prierezoch dejinnej skutočnosti: sú to roky druhej svetovej vojny a desatročia po nej, ale naliehavejšie sa im pozdáva reagovat ako generácia a deti svojich rodičov na nedávne desatročia, na osemdesiate roky a na to, čo po nich v spoločnosti nasledovalo, ked’ sa želania rozbíjali o novú realitu s „novou“ spoločenskou štruktúrou. Odvážne do týchto priesečníkov vstúpili svojimi prózami Oksana Zabužková a Juraj Andruchovyč.

16 Oksana Zabužko je v českom kultúrnom prostredí známa do češtiny preloženými prózami Polni výzkum ukrajinského sexu (2001), Sestro, sestro (2006), Muzem opuštěných tajemství (2013).

17 V publikácii Putováni současnou ukrajinskou literárni krajinou (2010) sa zvýrazňuje tvorba Jurija Andruchovyča, Jurija Izdryka, Tarasa Prochasku, Halyny Petrosaňakovej, Volodymyra Ješkiljeva, Jaroslava Dovhana a Marije Mykycejovej.

18 PROCHASKO, Taras: Z toho sa dá spravit’ niekol'ko poviedok. Bratislava: Brak, 2015, s. 9. 
vláde nezávislej Ukrajiny. Bol osemdesiaty tretí rok a začinali sa Andropovove represie. "19 Prítomnost' sa nestala očistou toho, čo pamät potomkov uchováva z toho, čo bolo, či ako to bolo, a Prochasko sa s odvrátenou stranou spoločenských zmien vyrovnáva bud' dramaticky, alebo tragicky, teda dostredivými, emocionálne sugestívnymi a nedávnej praxi blízkymi epizódami jednotlivcov, ktoré sa zaplnili smrtou Sofie, Iryny, Puňa ${ }^{20}$. Skúsenostný odtieň nesú v sebe epizódy, ktoré súdnost̉ nemôže akceptovat ani po ich uplynutí do politickej minulosti: „Môj brat bol v detskej zadržovačke z celkom iného dôvodu. Jeho záležitost' bola politická, pretože ho zatkli kágebáci. Jurko chcel odfotit' niekol'ko starých budov, ktoré mali byt' zbúrané. Obvinili ho z ideologickej diverzie - fotografie rozpadajúcich sa budov vraj chcel poslat’ do zahraničných časopisov, v ktorých mali ilustrovat’ reportáže o životných podmienkach sovietskych pracujúcich." ${ }^{21}$

Próza $Z$ toho sa dá spravit’ niekol'ko poviedok odkazuje tematikou a naračnými technikami do sugestívnej empírie autora už i tak, že sa zosúlad’uje s formálne miniatúrne organizovanou naráciou. I napriek tomu rozprávač uvádza nezvyčajne vel'ké množstvo postáv z detstva, štúdií, vojenskej služby, z práce v ústave na ochranu prírody a z rodičovského prostredia sú zapojení do jeho života, skúseností a rozpomienok spisovatela. Opakovane si rozprávač pripomína brata Juraja, no návraty k synom sú vyhrotenou emotívnou väzbou na život sám. K babke, ako ju nazýva, k jej tažkému osobnému a rodinnému osudu sa vracia na viacerých miestach až jej napokon venuje takmer výkladovo komponovanú časṫ v próze Ako som sa nestal spisovatel’om, medzi inými pripomína Jurija Andruchovyča ${ }^{22}$. Po prvý raz v širokom historicko-kultúrnom priestore takto „John Siddhartha, potulný väzeň nottinghamský, ako ho nazval Jurko Andruchovyč v Pervrzii, ktorú mu venoval"23, po druhý raz v príbehovej sekvencii venovanej architektúre Lvova: „Potom monastyr, ktorý tak pekne opisal v básni Jurko Andruchovyč. “24

Spisovatel' v role rozprávača, ale vlastne beletrizovaný subjekt Tarasa Prochasku v prózach $Z$ toho sa dá spravit' niekol'ko poviedok a Ako som prestal byt'spisovatelom, obnovuje a napája sa na rušnú a rôznorodú kultúrnu atmosféru európskeho sveta dávnej i nedávnej minulosti, ako keby vyznával presvedčenie Iriny Čmyrevovej, podla ktorej „umenie l’udi napokon privedie k l’udskej tvári“25. Do epizód zapojil prozaik nemálo rozličných spoločenských informácií, priezvisk, odkazov na umenie a literárnu tvorbu, aby svoje úsilie byt (nebyt') spisovatel'om v službe l'udskosti, slušnosti a obetavosti sa zosúladil s kultúrnym svetom svojho deda: „Ale viem, že práve tak to robil vel'ký český spisovatel' Bohumil Hrabal,

19 Ibidem, s. 32.

20 Ibidem, s. 33: „V armáde sa vyhodil do vzduchu. [...].Ked’ vyzdravel, nechali ho tam slúžit’ d’alej. Mladi vojenski lekári Puña často v noci budievali, vešali ho na šnúru, odpočítali niekol'ko sekúnd, vytiahli mu hlavu zo slučky a potom oživovali."

21 Ibidem.

22 Jurij Andruchovyč je autor próz Rekreácia (1992, po slov. 2003), Perverzia (1996), ktoré prekročili priestor a reálny literárny život ukrajinskej kultúry a prekladajú ich do d’alších jazykov.

23 PROCHASKO, Taras: Z toho sa dá spravit’ niekol'ko poviedok. Bratislava: Brak, 2015, s. 22.

24 PROCHASKO, Taras: Ako som prestal byt'spisovatel'om. Bratislava: Brak, 2015, s. 80.

25 Vyňaté z rozhovoru, ktorý poskytla ruská kutátorka výtvarného umenia denníku Sme v sobotu 14. 6. 2008. 
o ktorom som sa raz pokúšal niečo povedat. Jeho talent spočival v umení neoddelovat' každodenný život od každodennej literatúry. Ziskala na tom literatúra. Potom aj život môže byt’ iný. "26

Ak zblíženie sa s prozaikom, priatel’om nekaždodennej literárnej reči a spontánneho života naplneného talentom, tvorbou, slobodou a človečinou, svet Bohumila Hrabala, si uchováva tak zásadný význam pre existenciu a tvorbu Tarasa Prochasku a jeho humanizačným zmyslom naplnenú prítomnost๋ v ukrajinskej kultúre a literatúre dneška, otvára sa pre neho a jeho čitatel’ov jav poznania a zažívania každodennej literatúry, ktorá obstojí v čase a morálke l’udského činu a myšlienok.

\section{Literatúra}

CHLAŇOVÁ, Tereza a kol.: Putováni současnou ukrajinskou literárni krajinou. Prozaická tvorba představitelu tzv. „stanislavského fenoménu“. Praha: Pavel Mervart, 2010.

POSPÍŠIL, Ivo: Genologie a proměny literatury. Brno: Filozofická fakulta Masarykovy univerzity, 1998.

POSPÍŠIL, Ivo: Literárni postava jako „zašité nůžky“ literárni vědy. In: Sborník prací Filozofické fakulty Brněnské univerzity, roč. 50, X 4 (2001), s. 51-57.

PROCHASKO, Taras: Ako som prestal byt' spisovatelom. Bratislava: Brak, 2015.

PROCHASKO, Taras: Jinaci. Praha: Pavel Mervart, 2013.

PROCHASKO, Taras: Z toho sa dá spravit niekol'ko poviedok. Bratislava: Brak, 2015.

STACHOVÁ, Jiřina (ed.): Model a analogie ve vědě, uměni a filozofii. Praha: Filosofia - nakladatelství Filosofického ústavu AV ČR, 1994.

prof. PhDr. Viera Žemberová, CSc.

Inštitút slovakistických, mediálnych a knižničných štúdií

Filozofická fakulta, Prešovská univerzita v Prešove

UI. 17. novembra č. 1, 08001 Prešov, Slovenská republika

viera.zemberova@unipo.sk

26 PROCHASKO, Taras: Ako som prestal byt' spisovatel'om, Bratislava: Brak, 2015, s. 81. 